\title{
Optimasi Produksi Inulinase oleh Khamir Pichia manshurica DUCC Y-015 pada Tepung Umbi Dahlia (Dahlia variabilis Willd.) dengan Variasi Konsentrasi $\mathrm{K}_{2} \mathrm{HPO}_{4}$ dan Waktu Inkubasi
}

\author{
Inggrit Amedia, Wijanarka, Susiana Purwantisari. \\ Laboratorium Bioteknologi \\ Departemen Biologi, Fakultas Sains dan Matematika, Universitas Diponegoro, Semarang \\ Jln Prof. Soedarto, SH,Semarang,50275, Telp: (024)7474754; Fax (024) 76480923 \\ Email : Inggritamedia@gmail.com
}

\begin{abstract}
Sugar national supply more and more decreases and can not meet the market needs. The research has been done to find alternative natural sweeteners including inulin from dahlia tubers (D. variabilis Willd). Dahlia tuber can produce $95 \%$ of yield of fructose syrup in an enzimatic reaction by inulinase (E.C.3.2.1.7). Inulinase is inductive enzyme that can be produce by $P$. manshurica. The production of fructose needs to be optimized to get optimum product. The optimization can be done by modifying the nutrient content in the medium such as $\mathrm{K}_{2} \mathrm{HPO}_{4}$ and variation of incubation time. The purpose of this study is to determine the concentration of $\mathrm{K}_{2} \mathrm{HPO}_{4}$ and optimum incubation time for P. manshurica. This research was conducted in Microbiology Laboratory, Biology Department, Faculty of Science and Mathematics Undip. The examined variable is the growth of yeast cell, inulinase activity, invertase, and the $\mathrm{I} / \mathrm{S}$ ratio. This research was conducted experimentally using Randomized Complete Block Design (RCBD) factorial pattern with 2 factors, the first factor was the concentration of $\mathrm{K}_{2} \mathrm{HPO}_{4}(\mathrm{P})$, with concentration level $(\mathrm{g} / \mathrm{L})$ of $0.5\left(\mathrm{P}_{1}\right), 1.0\left(\mathrm{P}_{2}\right)$, and $1.5\left(\mathrm{P}_{3}\right)$. The second factor was incubation time $(\mathrm{W})$ with 12 hours $\left(\mathrm{W}_{12}\right), 18$ hours $\left(\mathrm{W}_{18}\right)$, and 24 hours $\left(\mathrm{W}_{24}\right)$. Every treatment was repeated three times. The collected data were analyzed using ANOVA. If there was a treatment effect, it will be continued with Duncan test on 5\% significance level. The result of analysis show that the highest cell growth and the maximum production of inulinase enzyme was in $\mathrm{P}_{3} \mathrm{~W}_{24}$ occurs in $\mathrm{P}_{3} \mathrm{~W}_{24}\left(\mathrm{~K}_{2} \mathrm{HPO}_{4} 1.5 \mathrm{~g} / \mathrm{L}\right.$ and 24 hours incubation time) treatment at $0.428 \mathrm{IU}$, but efficient in $\mathrm{P}_{1} \mathrm{~W}_{12}$ treatment as much as $0.365 \mathrm{IU}$.
\end{abstract}

Keywords: Dahlia variabilis Willd., Inulinase, $\mathrm{K}_{2} \mathrm{HPO}_{4}$, Pichia manshurica DUCC Y-015, incubation time

\begin{abstract}
Abstrak
Stok gula nasional semakin menurun dan tidak dapat memenuhi kebutuhan pasar. Penelitian telah dilakukan untuk mencari pemanis alami alternatif, termasuk inulin dari umbi dahlia (D. variabilis Willd.). Umbi dahlia dapat menghasilkan 95\% rendemen sirup fruktosa dalam satu tahap reaksi enzimatis oleh inulinase (E.C.3.2.1.7). Enzim inulinase merupakan enzim induktif yang dapat dihasilkan oleh khamir P. manshurica. Produksi fruktosa perlu dioptimasi untuk mendapatkan produk optimum. Optimasi dapat dilakukan dengan memodifikasi kandungan nutrisi dalam medium, seperti $\mathrm{K}_{2} \mathrm{HPO}_{4}$ dan variasi waktu inkubasi. Tujuan dari penelitian ini adalah menentukan konsentrasi $\mathrm{K}_{2} \mathrm{HPO}_{4}$ dan waktu inkubasi optimum bagi $P$. manshurica. Penelitian dilakukan di Laboratorium Mikrobiologi jurusan Biologi FSM Undip. Variabel yang diamati adalah pertumbuhan sel khamir, aktivitas enzim inulinase, invertase, dan rasio I/S. Penelitian dilakukan secara eksperimental menggunakan Rancangan Acak Kelompok (RAK) pola faktorial dengan 2 faktor. Faktor pertama berupa konsentrasi $\mathrm{K}_{2} \mathrm{HPO}_{4}(\mathrm{P})$ dengan taraf konsentrasi $(\mathrm{g} / \mathrm{L}) 0.5\left(\mathrm{P}_{1}\right), 1.0\left(\mathrm{P}_{2}\right)$, dan $1.5\left(\mathrm{P}_{3}\right)$. Faktor kedua berupa waktu inkubasi (W) dengan taraf 12 jam $\left(\mathrm{W}_{12}\right)$, 18 jam $\left(\mathrm{W}_{18}\right)$, dan 24 jam $\left(\mathrm{W}_{24}\right)$. Setiap perlakuan dilakukan pengulangan sebanyak 3 kali. Data yang diperoleh dianalisis menggunakan ANOVA, apabila terdapat pengaruh perlakuan dilanjutkan dengan uji Duncan pada taraf signifikasi $5 \%$. Hasil penelitian menunjukkan bahwa pertumbuhan sel tertinggi dan aktivitas enzim inulinase maksimum pada perlakuan $\mathrm{P}_{3} \mathrm{~W}_{24}$ (konsentrasi $\mathrm{K}_{2} \mathrm{HPO}_{4} 1.5 \mathrm{~g} / \mathrm{L}$ dan waktu inkubasi $24 \mathrm{jam}$ ) sebesar $0.428 \mathrm{IU}$, namun efisien pada pada perlakuan $\mathrm{P}_{1} \mathrm{~W}_{12}$ sebesar $0.365 \mathrm{IU}$.
\end{abstract}


Kata kunci : Dahlia variabilis, Inulinase, $\mathrm{K}_{2} \mathrm{HPO}_{4}$, Pichia manshurica DUCC Y-015, waktu inkubasi

\section{PENDAHULUAN}

Gula dikategorikan sebagai komoditi pokok kebutuhan manusia, namun stok gula nasional tidak mampu menutupi kebutuhan gula di pasaran. Stok gula nasional diperkirakan semakin menurun pada tahun 2014. Pasar gula Indonesia secara total adalah 5,7 juta ton pada tahun 2012, sedangkan produksi gula dalam negeri sebesar 2,6 juta ton yang berasal dari tebu petani dan pabrik gula (Harianto 2014). Berbagai penelitian telah dilakukan untuk mencari sumber pemanis alami alternatif yang aman bagi kesehatan, seperti inulin dalam umbi dahlia (D. variabilis Willd.) (Wijanarka dkk., 2007).

Umbi dahlia merupakan salah satu umbi yang mengandung inulin (Pandey, 1999). Inulin adalah polimer dari unit-unit fruktosa dengan gugus terminal glukosa. Unit-unit fruktosa dalam inulin dihubungkan oleh ikatan $\beta(2 \rightarrow 1)$ glikosidik. Inulin dari tanaman biasanya mengandung 20 sampai beberapa ribu unit fruktosa (Roberfroid, 2005). Inulin dapat dihidrolisis oleh inulinase dari mikroba, dan menghasilkan fruktosa, glukosa, dan inulooligosakarida (IOS). Hidrolisis inulin dalam satu langkah katalisis secara enzimatik menghasilkan fruktosa lebih tinggi yaitu $95 \%$ fruktosa (Zhen et al., 2011).

Enzim inulinase merupakan enzim yang bersifat induktif, sehingga untuk menghasilkan enzim tersebut harus di induksi dengan senyawa yang mengandung inulin (Fernandes \& Jiang, 2013). Inulinase dikategorikan sebagai metabolit primer dan hanya diproduksi pada fase logaritmik karena induksi inulin dari medium (Wijanarka dkk., 2014). $\quad$ P. manshurica DUCC Y015 merupakan khamir yang mampu menghasilkan enzim inulinase.

Optimasi perlu dilakukan untuk meningkatkan produksi fruktosa dari inulin oleh khamir $P$. manshurica. Optimasi medium dapat dilakukan dengan cara merubah variabel independen seperti nutrisi, suhu, pH, dll (Skowronek \& Fiedurek, 2004).
Optimasi pada penelitian ini dilakukan dengan cara memberikan konsentrasi $\mathrm{K}_{2} \mathrm{HPO}_{4}$ berbagai variasi pada medium dan lama waktu inkubasi.

Dikalium hidrogen fosfat $\left(\mathrm{K}_{2} \mathrm{HPO}_{4}\right)$ merupakan senyawa penting dalam medium untuk pertumbuhan khamir $P$. manshurica DUCC Y015, dan aktivitas enzim inulinase. $\mathrm{K}_{2} \mathrm{HPO}_{4}$ merupakan salah satu garam mineral untuk pertumbuhan khamir (Kurtzman et al., 2011). $\mathrm{K}_{2} \mathrm{HPO}_{4}$ merupakan buffer penstabil osmotik. Buffer diperlukan untuk mengatur dan menjaga pH larutan (Nimerick, 1996 dalam Fink, 2013). Waktu inkubasi merupakan waktu yang dibutuhkan oleh enzim untuk berikatan dengan substrat. Waktu inkubasi untuk khamir berkisar antara 2-3 hari pada suhu $25^{\circ} \mathrm{C}$, tetapi beberapa strain mungkin memerlukan suhu dan waktu inkubasi berbeda, yang berkisar antara $4-42^{\circ} \mathrm{C}$, masing-masing dalam 1 hari sampai beberapa minggu (Kurtzman et al., 2011).

\section{BAHAN DAN METODE}

Penelitian ini dilaksanakan pada bulan Pebruari hingga Mei 2015 di Laboratorium Mikrobiologi Jurusan Biologi Fakultas Sains dan Matematika Universitas Diponegoro.

Bahan. Khamir P. manshurica DUCC Y015 tepung umbi dahlia (D. variabilis Willd.), inulin murni $1 \%$, sukrosa $1 \%$, medium produksi inulinase (Ertan et al., 2003), Inulinase Selecting Medium (ISM), reagen untuk analisis gula reduksi Dinitrosalicylic acid (DNS), buffer sodium asetat $0,1 \mathrm{M} \mathrm{pH} 5, \mathrm{NaOH}, \mathrm{HCl}$, dan agar.

\section{Pembuatan Kultur Stok dan Kultur Kerja (Ertan et al., 2003).}

Satu ose isolat khamir $P$. manshurica DUCC Y-015 diisolasikan ke dalam Inulinase Selecting Medium (ISM), kemudian diinkubasi pada suhu ruang selama 24 jam. Khamir yang telah tumbuh dalam kultur stok diinokulasikan ke dalam medium produksi untuk dijadikan kultur kerja. 


\section{Pembuatan Medium Produksi Inulinase (g/L) (Ertan et al., 2003).}

Tepung umbi dahlia sebanyak 30 gram, dilarutkan dalam $1 \mathrm{~L}$ akuades, dipanaskan dalam penangas sampai mendidih \pm 25 menit, disaring menggunakan kapas dan kertas saring. Hasil saringan didihkan, kemudian disaring kembali menggunakan kapas dan kertas saring. Ekstrak umbi dahlia yang diperoleh ditambahkan dengan $\mathrm{NH}_{4} \mathrm{NO}_{3} \quad 2,3$ gram; $\left(\mathrm{NH}_{4}\right)_{2} . \mathrm{HPO}_{4} 3,7$ gram; yeast ekstrak 1,5 gram $\mathrm{pH} 5 ; \mathrm{K}_{2} \mathrm{HPO}_{4} \quad 0,5$ gram pada perlakuan pertama $\left(\mathrm{P}_{1}\right) ; \mathrm{K}_{2} \mathrm{HPO}_{4} 1$ gram pada perlakuan kedua $\left(\mathrm{P}_{2}\right) ; \mathrm{K}_{2} \mathrm{HPO}_{4} 1,5$ gram pada perlakuan ketiga $\left(\mathrm{P}_{3}\right)$; dan $\mathrm{MgSO}_{4} .7 \mathrm{H}_{2} \mathrm{O} 0,5$ gram yang telah dilarutkan dalam $\mathrm{HCl} 5 \mathrm{~mL}$. Larutan dibuat menjadi $\mathrm{pH} 5$.

Pembuatan Starter Khamir P. manshurica DUCC Y-015 (Wijanarka dkk., 2013).

Satu ose isolat khamir $P$. manshurica DUCC Y-015 dinokulasikan ke dalam $50 \mathrm{~mL}$ medium produksi steril, $\mathrm{pH}$ 5, diinkubasi menggunakan rotary shaker dengan kecepatan agitasi $120 \mathrm{rpm}$ pada suhu ruang selama 22 jam, sehingga didapatkan kultur dengan kepadatan $10^{7} \mathrm{sel} / \mathrm{mL}$.

\section{Pengukuran Pertumbuhan Sel (Wijanarka dkk., 2013).}

Kultur dari starter diambil sebanyak 5 $\mathrm{mL}$ dan diinokulasikan pada masing-masing medium produksi dengan $\mathrm{K}_{2} \mathrm{HPO}_{4}$ berbagai konsentrasi (g/L), yaitu 0,5 (P1), 1 (P2), dan 1,5 (P3), kemudian diinkubasi dengan rotary shaker dengan kecepatan agitasi $120 \mathrm{rpm}$ pada suhu ruang. Pengambilan kultur dilakukan setiap 6 jam untuk mengukur pertumbuhan sel. Pertumbuhan sel ditentukan dengan mengukur nilai optical density (OD) menggunakan spektrofotometer pada $\lambda_{520} \mathrm{~nm}$. Pengukuran pertumbuhan merupakan penelitian pendahuluan untuk menentukan waktu inkubasi yang dipilih dalam uji aktivitas enzim.

\section{Produksi Enzim (Wijanarka dkk., 2008).}

Sampel diambil pada waktu inkubasi tertentu, yaitu jam ke-12 ( $\left.\mathrm{W}_{12}\right), 18\left(\mathrm{~W}_{18}\right)$ dan $24\left(\mathrm{~W}_{24}\right)$. Waktu-waktu tersebut merupakan waktu khamir menunjukkan kepadatan sel maksimum. Sampel kultur diambil sebanyak 5 $\mathrm{mL}$ dimasukkan ke dalam botol film. Sampel kultur yang diambil disentrifugasi pada kecepatan $3000 \mathrm{rpm}$ selama 10 menit. Supernatan yang diperoleh merupakan crude enzyme, dan digunakan untuk uji aktivitas enzim.

\section{Pengukuran Aktivitas Enzim (Xiao et al.,} 1988).

Pengukuran aktivitas inulinase dan invertase dilakukan untuk mengetahui rasio aktivitas relatif antara inulin dan sukrosa (rasio $\mathrm{I} / \mathrm{S})$. Aktivitas inulinase dan invertase didasarkan pada gula reduksi yang terbentuk. Gula reduksi diukur dengan cara menghitung absorbansi enzim substrat (ES) dikurangi dengan absorbansi substrat (S) dan enzim (E), sehingga diperoleh rumus sebagai berikut:

Aktivitas Enzim (IU)

$$
=\frac{(\text { fruktosa }}{\text { BM fruktosa } \times 30} \times \mathrm{P} \times 1000
$$

Keterangan : AbsES = absorbansi enzim substrat, $\mathrm{AbsE}=$ absorbansi enzim, AbsS = absorbansi Substrat, $\mathrm{BM}=$ berat molekul fruktosa $(180,1), \mathrm{P}=$ faktor pengenceran.

\section{Aktivitas Inulinase.}

Aktivitas inulinase ditentukan dengan menggunakan 4 jenis reaksi yaitu reaksi enzimsubstrat (ES), reaksi subsrat (S), reaksi enzim (E), dan reaksi blangko. Reaksi enzim-substrat (ES) berisi substrat inulin $1 \% 0,5 \mathrm{~mL}$; buffer asetat $0,4 \mathrm{~mL}$, dan crude enzyme $0,1 \mathrm{~mL}$. Reaksi substrat (S) berisi substrat inulin 1\% 0,5 $\mathrm{mL}$; buffer asetat $0,4 \mathrm{~mL}$, dan akuades $0,1 \mathrm{~mL}$. Reaksi enzim (E) berisi buffer asetat $0,4 \mathrm{~mL}$, crude enzyme $0,1 \mathrm{~mL}$, dan akuades $0,5 \mathrm{~mL}$. Reaksi blanko berisi buffer asetat $0,4 \mathrm{~mL}$ dan akuades 0,6 mL. Masing-masing reaksi diinkubasi pada suhu $50^{\circ} \mathrm{C}$ selama 30 menit. Reaksi dihentikan dengan memasukkan tabung sampel ke dalam air mendidih selama 2 menit, setelah dingin ditambahkan reagen Dinitosalicylic acid (DNS) sebanyak $1 \mathrm{~mL}$. 
Larutan dipanaskan ke dalam air mendidih selama 3 menit, dan setelah dingin, ditambahkan dengan $5 \mathrm{~mL}$ akuades. Pengukuran absorbansi dilakukan dengan spektrofotometer pada $\lambda_{570} \mathrm{~nm}$. Aktivitas inulinase dianalisis dengan metode DNS dan ditentukan berdasarkan sejumlah $1 \mu$ mol gula reduksi yang dibebaskan per menit berdasarkan kondisi tertentu.

\section{Aktivitas Invertase.}

Penentuan aktivitas invertase dilakukan sama seperti pada penentuan aktivitas inulinase, hanya saja yang berbeda adalah substratnya. Substrat yang digunakan adalah sukrosa $1 \%$.

\section{Pembuatan Kurva Fruktosa Standar (Sudarmadji dkk., 1989).}

Kurva fruktosa standar ditentukan dengan membuat larutan fruktosa pada konsentrasi yang berbeda yaitu $0 \mathrm{mg} / \mathrm{mL}, 0,2 \mathrm{mg} / \mathrm{mL}, 0,4$ $\mathrm{mg} / \mathrm{mL}, 0,6 \mathrm{mg} / \mathrm{mL}, 0,8 \mathrm{mg} / \mathrm{mL}$, dan $1 \mathrm{mg} / \mathrm{mL}$. Masing-masing larutan fruktosa yang berbeda konsentrasinya, diambil sebanyak $1 \mathrm{~mL}$, kemudian direaksikan dengan reagen DNS sebanyak $1 \mathrm{~mL}$. Larutan tersebut dipanaskan dalam air mendidih selama 10 menit hingga terjadi perubahan warna, dan didinginkan. Larutan diencerkan dengan $5 \mathrm{~mL}$ akuades dan diukur kerapatan optisnya menggunakan spektrofotometer pada $\lambda_{570} \mathrm{~nm}$. Hasil yang diperoleh adalah garis regresi hubungan antara kerapatan optis dengan konsentrasi larutan fruktosa standar. Aktivitas inulinase isolat khamir dapat diketahui berdasarkan garis regresi ini.

\section{Metode Analisis Data.}

Metode analisis data dilakukan secara eksperimental, menggunakan Rancangan Acak Kelompok (RAK) pola faktorial dengan 2 faktor. Faktor pertama tentang konsentrasi $\mathrm{K}_{2} \mathrm{HPO}_{4}\left(\mathrm{P}_{1}, \mathrm{P}_{2}, \mathrm{P}_{3}\right)$, dengan taraf konsentrasi $(\mathrm{g} / \mathrm{L})$ sebesar 0,5 $\left(\mathrm{P}_{1}\right), 1,0\left(\mathrm{P}_{2}\right)$, dan 1,5 $\left(\mathrm{P}_{3}\right)$. Faktor kedua berupa waktu inkubasi $\left(\mathrm{W}_{12}, \mathrm{~W}_{18}\right.$, $\mathrm{W}_{24}$ ) dengan taraf masing-masing 12 jam $\left(\mathrm{W}_{12}\right), 18$ jam $\left(\mathrm{W}_{18}\right)$, dan 24 jam $\left(\mathrm{W}_{24}\right)$. Masing-masing perlakuan dilakukan pengulangan sebanyak 3 kali. Data yang diperoleh dianalisis dengan menggunakan ANOVA apabila terdapat pengaruh perlakuan dilanjutkan dengan uji lanjut Duncan pada taraf signifikasi 5\%. Analisis data dilakukan menggunakan perangkat lunak SPSS 16.0, Minitab 17, SAS 9.1.3.

\section{HASIL DAN PEMBAHASAN}

Pertumbuhan khamir P. manshurica DUCC Y-015.

Pola pertumbuhan khamir $P$. manshurica DUCC Y-015 cenderung sama meskipun terdapat perbedaan pelakuan yang diberikan. Pertumbuhan sel khamir $P$. manshurica DUCC Y-015 maksimum pada waktu inkubasi 24 jam. Nilai absorbansi pertumbuhan maksimum terjadi pada perlakuan $\mathrm{P}_{3}$ (konsentrasi $\mathrm{K}_{2} \mathrm{HPO}_{4}$ 1,5 g/L) sebesar 1,036.

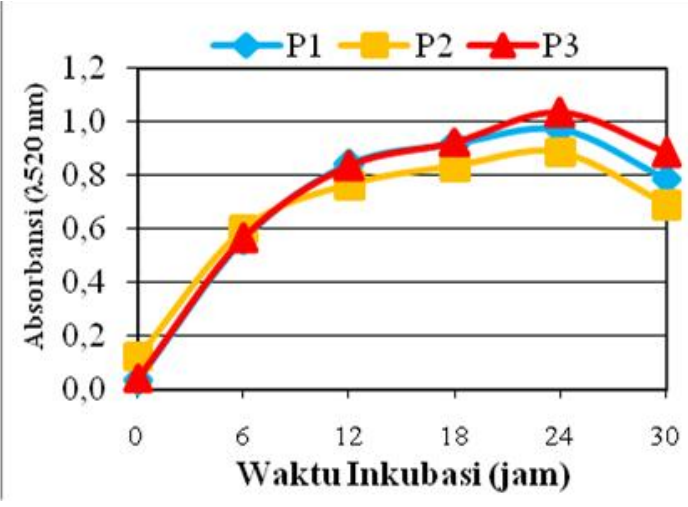

Gambar 1. Kurva pertumbuhan $P$. manshurica DUCC Y-015 pada variasi konsentrasi $\mathrm{K}_{2} \mathrm{HPO}_{4}$ dan waktu inkubasi

$\mathrm{P}_{1}=$ Konsentrasi $\mathrm{K}_{2} \mathrm{HPO}_{4}$ 0,5 gram $/ \mathrm{L}$

$\mathrm{P}_{2}=$ Konsentrasi $\mathrm{K}_{2} \mathrm{HPO}_{4} 1$ gram $/ \mathrm{L}$

$\mathrm{P}_{3}=$ Konsentrasi $\mathrm{K}_{2} \mathrm{HPO}_{4} 1,5 \mathrm{gram} / \mathrm{L}$

Gambar 1 menunjukkan, bahwa fase lag (fase adaptasi) pada pertumbuhan khamir $P$. manshurica DUCC Y-015 tidak terjadi. Hal ini disebabkan, karena penggunaan starter $10 \%$ pada saat inokulasi, yang mengakibatkan tidak akan terjadi fase lag. Madigan et al. (2012) mengungkapkan, Kultur yang telah tumbuh secara eksponensial pada medium starter, kemudian ditransfer ke medium dengan kondisi pertumbuhan (suhu, aerasi, dan sejenisnya) 
yang sama, maka fase lag tidak terjadi dan pertumbuhan eksponensial segera dimulai.

Fase eksponensial mulai terjadi pada waktu inkubasi 0 jam $\left(\mathrm{W}_{0}\right)$ sampai 12 jam $\left(\mathrm{W}_{12}\right)$. Fase eksponensial merupakan fase, ketika sel khamir mengalami pembelahan sel sangat cepat dalam waktu yang konstan. Hogg (2005) menyatakan, bahwa fase eksponensial merupakan fase, ketika sel mikroorganisme dalam kondisi stabil dan memiliki kemampuan untuk membelah secara optimum, laju pertumbuhan dan aktivitas metabolik konstan.

Fase stasioner mulai terjadi pada rentang waktu inkubasi $12\left(\mathrm{~W}_{12}\right)$ sampai 24 jam $\left(\mathrm{W}_{24}\right)$. Adam \& Moss (2008) mengungkapkan, bahwa fase eksponensial berakhir disebabkan, karena terjadinya perubahan komposisi pada medium pertumbuhan.

Pertumbuhan sel memasuki fase kematian setelah waktu inkubasi 24 jam $\left(\mathrm{W}_{24}\right)$. Kepadatan sel khamir semakin menurun dilihat dari nilai absorban yang semakin rendah. Penurunan kepadatan sel ini disebabkan, karena nutrien dalam medium pertumbuhan sudah habis. Inulin sebagai satu-satunya sumber karbon pada medium tidak tersedia lagi. Madigan (2012) menyatakan, bahwa semua sel membutuhkan karbon. Karbon merupakan elemen esensial untuk seluruh mikroorganisme. Karbon dibutuhkan dalam jumlah yang sangat tinggi mencapai $50 \%$ berat kering, karena seluruh sel membutuhkan jumlah yang besar untuk membuat material sel baru

\section{Produksi Enzim Inulinase oleh manshurica DUCC Y-015.}

$\boldsymbol{P}$.

Jumlah inulinase yang diproduksi dapat ditentukan dengan pengukuran aktivitas enzim (Sadikin, 2002). Berdasarkan nilai aktivitas enzim pada hasil penelitian yang telah dilakukan menunjukkan, bahwa aktivitas inulinase maksimum terdapat pada perlakuan $\mathrm{P}_{3} \mathrm{~W}_{24}$ (konsentrasi $\mathrm{K}_{2} \mathrm{HPO}_{4} \quad 1,5$ gram dan waktu inkubasi 24 jam) sebesar 0,428 IU. Perlakuan $\mathrm{P}_{1}$ (konsentrasi $\mathrm{K}_{2} \mathrm{HPO}_{4}$ 0,5 gram) maksimum terjadi pada waktu inkubasi 12 jam $\left(\mathrm{W}_{12}\right)$ sebesar 0,365 IU, sedangkan perlakuan $\mathrm{P}_{2}$ (konsentrasi $\mathrm{K}_{2} \mathrm{HPO}_{4} 1$ gram) maksimum terjadi pada waktu inkubasi 18 jam sebesar 0,366 IU.

Nilai aktivitas maksimum inulinase yang diperoleh (Gambar 2) memperlihatkan adanya pengaruh interaksi pemberian konsentrasi $\mathrm{K}_{2} \mathrm{HPO}_{4}$ dan waktu inkubasi yang berbeda. Semakin lama waktu inkubasi, maka semakin tinggi konsentrasi $\mathrm{K}_{2} \mathrm{HPO}_{4}$ yang dibutuhkan. $\mathrm{Hal}$ ini disebabkan, karena $\mathrm{K}_{2} \mathrm{HPO}_{4}$ berfungsi sebagai buffer penstabil osmotik yang dapat mempertahankan konsentrasi ion $\mathrm{H}^{+}$dan $\mathrm{OH}^{-}$di dalam medium, sehingga $\mathrm{pH}$ medium stabil. Hal ini sesuai dengan Madigan (2012) yang menyatakan, bahwa di dalam kultur batch, $\mathrm{pH}$ dapat berubah selama pertumbuhan, sebagai akibat dari reaksi metabolisme mikroorganisme yang mengkonsumsi atau menghasilkan zat asam atau basa. Buffer ditambahkan ke dalam medium kultur untuk menjaga $\mathrm{pH}$ relatif konstan.

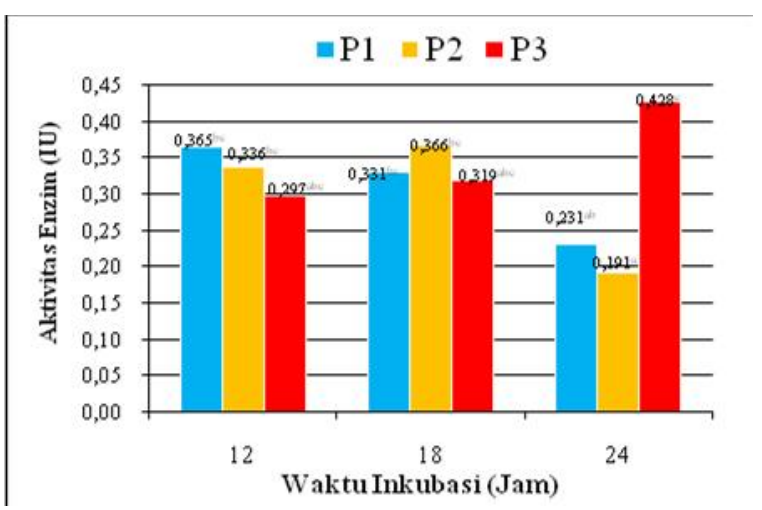

Gambar 2. Diagram batang aktivitas inulinase $P$. manshurica DUCC Y-015 pada variasi konsentrasi $\mathrm{K}_{2} \mathrm{HPO}_{4}$ dan waktu inkubasi.

Nilai aktivitas enzim yang diikuti dengan superskrip yang sama menunjukkan perbedaan tidak signifikan $\mathrm{P}_{1}=$ Konsentrasi $\mathrm{K}_{2} \mathrm{HPO}_{4}$ 0,5 gram/L

$\mathrm{P}_{2}=$ Konsentrasi $\mathrm{K}_{2} \mathrm{HPO}_{4} 1 \mathrm{gram} / \mathrm{L}$

$\mathrm{P}_{3}=$ Konsentrasi $\mathrm{K}_{2} \mathrm{HPO}_{4}$ 1,5 gram $/ \mathrm{L}$

Nilai aktivitas enzim yang diperoleh membuktikan, bahwa kultur $P$. manshurica DUCC Y-015 dapat tumbuh dengan baik dalam medium produksi inulin dan menghasilkan enzim inulinase. Enzim inulinase dapat menggunakan inulin sebagai satu-satunya 
sumber karbon untuk dihidrolisis menjadi fruktosa. Vandamme \& Derycke (1983) mengungkapkan, bahwa penambahan inulin sebagai sumber karbon merupakan prasyarat untuk pembentukan enzim. Penelitian Lunggani dkk. (2009) mengungkapkan, bahwa semakin besar konsentrasi sumber karbon (inulin) yang diberikan maka akan berpengaruh positif terhadap produksi enzim inulinase (produksinya semakin besar). Hal ini disebabkan, karena inulin dapat berfungsi induser. Induser berfungsi untuk meningkatkan produksi enzim dikarenakan terjadinya penempelan RNA polimerase pada promoter.

Hasil analisis sidik ragam pengaruh variabel independen (konsentrasi $\mathrm{K}_{2} \mathrm{HPO}_{4}$ dan waktu inkubasi) terhadap variabel dependen (aktivitas enzim inulinase), menunjukkan bahwa interaksi $\mathrm{P} \times \mathrm{W}$ (interaksi konsentrasi $\mathrm{K}_{2} \mathrm{HPO}_{4}$ dan waktu inkubasi) berpengaruh nyata terhadap aktivitas enzim, namun setelah dilakukan uji lanjut Duncan pada taraf signifikansi 95\% menunjukkan, bahwa $\mathrm{P}_{3} \mathrm{~W}_{24}$ dengan aktivitas iunilinase tertinggi tidak berbeda secara signifikan dengan perlakuan lainnya. Hal ini dapat dijadikan sebagai referensi untuk memproduksi enzim inulinase secara efisien, yaitu pada perlakuan $\mathrm{P}_{1} \mathrm{~W}_{12}$.

\section{Produksi Enzim Invertase oleh manshurica DUCC Y-015.}

$\boldsymbol{P}$.

Aktivitas enzim invertase didefinisikan sebagai kecepatan suatu enzim dalam mengkatalis substrat. Perhitungan aktivitas invertase dimaksudkan untuk dapat membandingkan nilai aktivitas enzim inulinase dan invertase, sehingga diperoleh nilai kompleks enzimatik. Sharma et al. (2006) menyatakan, bahwa aktivitas inulinase (I) umumnya disertai dengan aktivitas invertase (S) dan kompleks enzimatik.

Hasil penelitian yang telah dilakukan menunjukkan, bahwa aktivitas invertase tertinggi terdapat pada perlakuan $\mathrm{P}_{1} \mathrm{~W}_{18}$ $\left(\mathrm{K}_{2} \mathrm{HPO}_{4}\right.$ 0,5 gram dan waktu inkubasi 18 jam) sebesar 0,332 IU. Pada perlakuan $\mathrm{P}_{2}$ (konsentrasi $\mathrm{K}_{2} \mathrm{HPO}_{4} 1$ gram) aktivitas enzim $P$. manshurica DUCC Y-015 tertinggi terjadi pada waktu inkubasi 12 jam sebesar 0,280 IU, sedangkan pada perlakuan $\mathrm{P}_{3}$ (konsentrasi $\mathrm{K}_{2} \mathrm{HPO}_{4} \quad 1,5$ gram) aktivitas $P$. manshurica DUCC Y-015 tertinggi terjadi pada waktu inkubasi 24 jam sebesar 0,300 IU (Gambar 3).

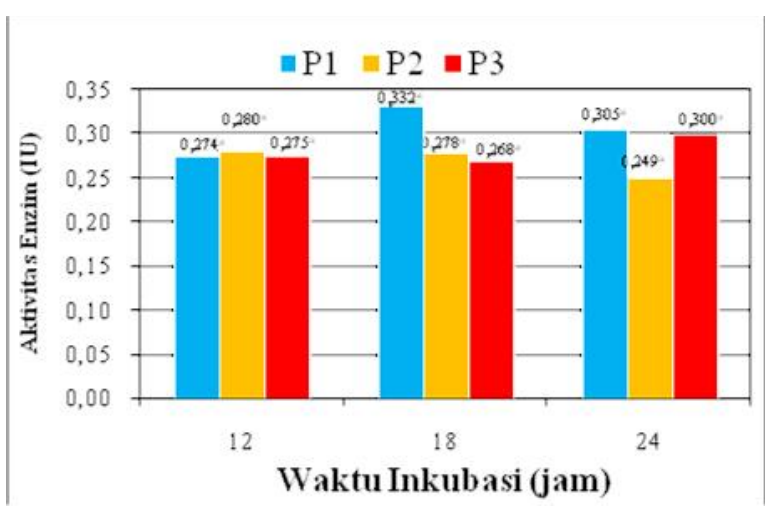

Gambar 3. Diagram batang aktivitas invertase $\quad P$. manshurica DUCC Y-015 pada variasi konsentrasi $\mathrm{K}_{2} \mathrm{HPO}_{4}$ dan waktu inkubasi.

Nilai aktivitas enzim yang diikuti denga superskrip yang sama menunjukkan perbedaan tidak signifikan $\mathrm{P}_{1}=$ Konsentrasi $\mathrm{K}_{2} \mathrm{HPO}_{4} 0,5$ gram $/ \mathrm{L}$

$\mathrm{P}_{2}=$ Konsentrasi $\mathrm{K}_{2} \mathrm{HPO}_{4} 1$ gram $/ \mathrm{L}$

$\mathrm{P}_{3}=$ Konsentrasi $\mathrm{K}_{2} \mathrm{HPO}_{4} 1,5 \mathrm{gram} / \mathrm{L}$

Perlakuan $\mathrm{P}_{1}$ (konsentrasi $\mathrm{K}_{2} \mathrm{HPO}_{4} \quad 0,5$ gram) relatif memiliki nilai aktivitas invertasi lebih tinggi dari perlakuan $\mathrm{P}_{2}$ (konsentrasi $\mathrm{K}_{2} \mathrm{HPO}_{4} 1$ gram) dan $\mathrm{P}_{3}$ (konsentrasi $\mathrm{K}_{2} \mathrm{HPO}_{4}$ 1,5 gram). Hal ini disebabkan, karena semakin naiknya konsentrasi $\mathrm{K}_{2} \mathrm{HPO}_{4}$ menyebabkan medium menjadi hipertonis, sehingga nutiren dapat msuk ke dalam sel tidak sebanyak pada perlakuan $\mathrm{P}_{1}$.

Berdasarkan hasil analisis sidik ragam (Anova) pengaruh variabel independen (konsentrasi $\mathrm{K}_{2} \mathrm{HPO}_{4}$, waktu inkubasi) terhadap variabel dependen (aktivitas enzim inulinase) menunjukkan, bahwa seluruh perlakuan tidak memberikan pengaruh secara signifikan terhadap aktivitas enzim (Tabel L.9.).

\section{Rasio I/S P. manshurica DUCC Y-015}

Perhitungan rasio I/S dilakukan dengan membagi nilai aktivitas enzim inulinase dengan nilai aktivitas enzim invertase. Oleh karena itu, 
tinggi rendahnya aktivitas enzim akan berpengaruh terhadap rasio I/S.

Rasio I/S P. manshurica DUCC Y015 menunjukkan, bahwa enzim yang berkerja pada proses hidrolisis adalah enzim inulinase. Hal ini sesuai dengan Skowronek (2003) yang menyatakan, bahwa apabila nilai rasio I/S lebih dari 1 maka enzim tersebut termasuk inulinase, namun apabila nilai rasio I/S kurang dari 1 maka enzim tersebut termasuk invertase (Gambar 4).

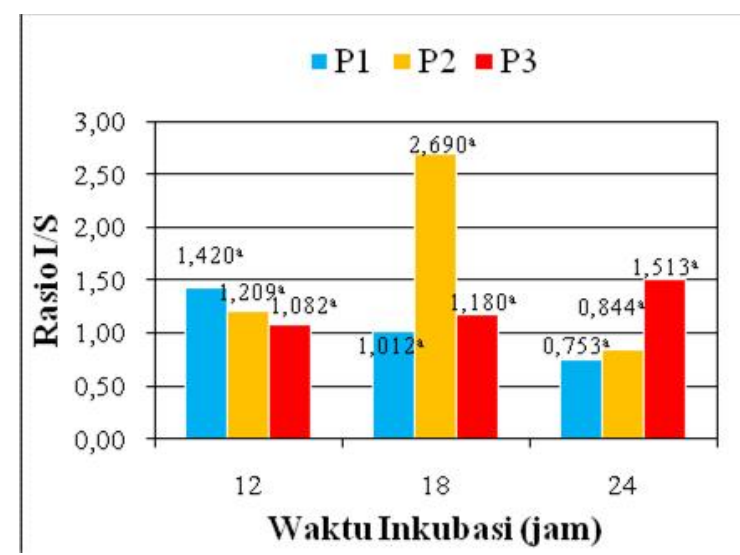

Gambar 4. Diagram barang rasio I/S khamir P. manshurica DUCC Y-015 pada variasi konsentrasi $\mathrm{K}_{2} \mathrm{HPO}_{4}$ dan waktu inkubasi.

Nilai aktivitas enzim yang diikuti dengan superskrip yang sama menunjukkan perbedaan tidak signifikan $\mathrm{P}_{1}=$ Konsentrasi $\mathrm{K}_{2} \mathrm{HPO}_{4}$ 0,5 gram $/ \mathrm{L}$

$\mathrm{P}_{2}=$ Konsentrasi $\mathrm{K}_{2} \mathrm{HPO}_{4} 1$ gram $/ \mathrm{L}$

$\mathrm{P}_{3}=$ Konsentrasi $\mathrm{K}_{2} \mathrm{HPO}_{4}$ 1,5 gram/L

Hasil penelitian menunjukkan rasio I/S tertinggi terdapat pada perlakuan $\mathrm{P}_{2} \mathrm{~W}_{18}$ (konsentrasi $\mathrm{K}_{2} \mathrm{HPO}_{4} 1$ gram dan waktu inkubasi 18 jam) sebesar 2,690, sedangkan pada perlakuan $\mathrm{P}_{1}$ (konsentrasi $\mathrm{K}_{2} \mathrm{HPO}_{4} \quad 0,5$ gram) rasio I/S tertinggi terjadi pada waktu inkubasi 12 jam sebesar 1,420 dan pada perlakuan $\mathrm{P}_{3}$ (konsentrasi $\mathrm{K}_{2} \mathrm{HPO}_{4}$ 1,5 gram) terjadi pada waktu inkubasi 24 jam sebesar 1,513 .

Berdasarkan hasil analisis sidik ragam (Anova) pengaruh konsentrasi $\mathrm{K}_{2} \mathrm{HPO}$ dan waktu inkubasi terhadap aktivitas enzim inulinase menunjukkan, bahwa seluruh perlakuan tidak memberikan pengaruh secara signifikan.

\section{KESIMPULAN}

Interaksi konsentrasi $\mathrm{K}_{2} \mathrm{HPO}_{4}$ dan waktu inkubasi berpengaruh secara signifikan terhadap aktivitas enzim inulinase. Aktivitas inulinase khamir $\quad$ P. manshurica DUCC Y-015 maksimum pada konsentrasi $\mathrm{K}_{2} \mathrm{HPO}_{4}$ $1,5 \mathrm{~g} / \mathrm{L}$ dan waktu inkubasi 24 jam sebesar 0,428 IU, namun untuk efisiensi dapat dilakukan pada konsentrasi $\mathrm{K}_{2} \mathrm{HPO}_{4} 0,5 \mathrm{~g} / \mathrm{L}$ dan waktu inkubasi 12 jam sebesar 0,365 IU.

\section{UCAPAN TERIMAKASIH}

Penulis mengucapkan banyak terimakasih kepada Bapak Dr. Drs. Wijanarka, M.Si yang telah memberikan kesempatan kepada penulis untuk bergabung dalam projek penelitian tentang inulin pada tahun 2014, juga kepada Ibu Dra. Susiana Purwantisari, M.Si atas bimbingannya kepada penulis.

\section{DAFTAR PUSTAKA}

Adam, M. R. and M. O. Moss. 2008. Food Microbiology. $3^{\text {rd }}$ Edition. The Royal Society of Chemistry. Cambridge, UK. 20-52.

Ertan, F., T. Aktac, A. C. Kaboglu, F. Ekinci, and E. Bakar. 2003. Determination of Optimum Cultivation Condition on the Production of Inulinase from Rhizoctonia solani. Pakistan J. Biological Sci. 6 (16) : 1386-1388.

Fernandes, M. R. V. S and B. Jiang. 2013. Fungal Inulinases as Potential Enzymes for Application in the Food Industry. $J$. Food Sci. and Tech. 5(8): 1031-1042.

Fink, J. K. 2013. pH Control Additives. Hydraulic Fracturing Chemicals and Fluids Technology. 115-119.

Harianto. 2014. Mengatasi Masalah Gula Nasional.http://www.indonesia.go.id/in/k ementerian/kementerian/kementeriansekretariat-negara/3086-panganene rgi/13797-mengatasi-masalah-gula-na sional-. Diakses pada tanggal 5 Januari 2015. 
Kurtzman, C. P. Pichia E.C. Hansen (1904). In C.P. Kurtzman, J.W. Fell \& T. Boekhout (Eds.) The yeast: A taxonomic study. $5^{\text {th }}$ edition. Elsevier. 685-698.

Lunggani, A. T., Wijanarka, dan E. Kusdiyantini. 2009. Penapisan Khamir Inulinolitik Jawa Tengah dan Pengujian Aktivitas Inulinasenya. Seminar Nasional Peran Biosistematiika dalam Pengelolaan Sumber Daya Alam Hayati Indonesia di Unsoed-Purwokwerto. 1-10.

Madigan, M. T., J. M. Martinko, D. A. Stahl, and D. P. Clark. 2012. Biology of Microorganisms. 13 ${ }^{\text {th }}$ Edition. Pearson education, Inc. San Franscisco. 117-128.

Sharma, A. D., S. Kainth, and P. K. Gill. 2006. Inulinase Production Using Garlic (Allium sativum) Powder as a Potential Substrate in Streptomyces sp. J. Food Eng. 77 (3) : 486-491.

Skowronek, M., K. Justynna, F. Jan, G. Anna. 2003. Invertase Activity of Psychotropic Fungi. Department of Industrial Microbiology. Maria CurieSklowdowska University. J. vol LVIII Akademicka. 19 : 20-033. and J. Fiedurek. 2004. Optimisation of Inulinase Production by Aspergillus niger using Simplex and Classical Method. Food Technol. Biotechnol. 42 (3) : 141-146.

Sudarmaji, S, dkk. 1989. Analisa Bahan Makanan dan Pertanian. Penerbit Liberty. Yogyakarta.

Vandamme, E. J. and D. G. Derycke. 1983. Microbial Inulinases : Fermentation Process, Properties, and Applications.
Advances in App. Microbiol. 29 : 139176.

Roberfroid, M. B. 2005. Introducing Inulintype fructans. British J. Nutrition 93 (1) : S13 - S25.

Wijanarka, M. G. I. Rukmi, dan L. Sutrisna. 2007. Pengaruh Pepton dan Waktu Inkubasi terhadap Produksi Inulinase oleh Pichia alni DUCC-W4 Berbahan Dasar Tepung Umbi Dahlia (Dahlia variabilis Willd.). BIOMA 9 (2) : 52-57.

R. S. Ferniah, dan Salamah. 2008. Produksi Inulinase Pichia alni DUCCW4 pada Tepung Umbi Dahlia (Dahlia variabilis Willd) dengan Variasi Konsentrasi Ammonium Nitrat dan Waktu Inkubasi. BIOMA 10 (2) : 58-64.

E.S. Soetarto, K. Dewi, dan A. Indrianto. 2013. Aktivitas Inulinase Oleh Pichia manshurica dan Fusan F4 Pada Fermentasi Batch Dengan Umbi Dahlia (Dahlia Sp.) Sebagai Substrat. $J$. Reaktor. Terakreditasi. 14 (3) : 187192.

. 2014. Intergenus Protoplast Fusion between Pichia manshurica and Rhodosporidium paludigenumto Increase the Production of Inulinase. Makara J. Sci. Terakreditasi 18 (4) : 101-105.

Zhen, M. C., Tong, Z., Tian, S. C., Xiao, Y. L., Wei, C., and Chun, H. Z. 2011. Biotechnological Potential of Inulin for Bioprocesses. Bioresource Tech. 102 : 42954303. 